\title{
Cheese bread enriched with biofortified cowpea flour
}

\section{Pão de queijo enriquecido com farinha de feijão-caupi biofortificado}

\author{
Rodrigo Barbosa Monteiro Cavalcante', Marcelo Antônio Morgano², \\ Kaesel Jackson Damasceno e Silva ${ }^{3}$, Maurisrael de Moura Rocha ${ }^{3}$, \\ Marcos Antônio da Mota Araújo ${ }^{4}$, Regilda Saraiva dos Reis Moreira-Araújo ${ }^{5 *}$
}

\author{
'Universidade Federal do Piauí/UFPI, Teresina, PI, Brasil \\ ${ }^{2}$ Instituto de Tecnologia de Alimentos/ITAL, Centro de Pesquisa e Desenvolvimento de Química de Alimentos e Nutrição Aplicada, Campinas, SP, Brasil \\ ${ }^{3}$ Empresa Brasileira de Pesquisa Agropecuária/Embrapa, Teresina, PI, Brasil \\ ${ }^{4}$ Fundação Municipal de Saúde, Teresina, PI, Brasil \\ 5Universidade Federal do Piauí/UFPI, Departamento de Nutrição, Teresina, PI, Brasil \\ *Corresponding author: regilda@ufpi.edu.br; regilda.saraiva@pq.cnpq.br \\ Received in may 29, 2015 and approved october 5, 2015
}

\begin{abstract}
The development and enrichment of food are of great importance not only for the industry but also to improve the population's nutrition, where you can create new products or optimize existing ones. The consumption of fortified products in the diet is an option for the control of deficiency diseases. This study aimed to develop enriched cheese bread with whole biofortified cowpea flour and evaluate their acceptance and chemical composition. Two formulations, F1 and F2, were prepared containing 5.6 and $8 \%$ of cowpea flour as a substitute for starch, respectively. To check acceptance, three sensory tests were used (Hedonic Scale, Purchase Intent, and Paired Comparison), F1 being sensory viable according to assessors, being chemically analyzed. Minerals were determined by atomic emission spectrometry with inductively coupled plasma source. The moisture was determined by drying at $105^{\circ} \mathrm{C}$, ash by calcination in muffle at $550{ }^{\circ} \mathrm{C}$, proteins by the macro-Kjeldahl method, and lipids by hot extraction in a Soxhlet extractor. Carbohydrates were obtained by difference and the calories were calculated. The addition of cowpea increased the amounts of copper, iron, phosphorus, magnesium, manganese, and zinc, as well as protein and carbohydrate values. On the other hand, there was a reduction of the moisture concerning lipids and the total caloric value compared to the standard formulation. It was concluded, therefore, that the cowpea, a regional raw material in market expansion is presented as an option for the enrichment of baked foods that do not contain gluten, such as cheese bread.
\end{abstract}

Index terms: Bakery product; fortification; Vigna unguiculata (L.) Walp.

\section{RESUMO}

O desenvolvimento e enriquecimento de alimentos têm grande importância não só para a indústria, como também para a melhoria da nutrição da população, onde se pode criar novos produtos ou otimizar os já existentes. O consumo de produtos enriquecidos na dieta representa uma opção para o controle das doenças carenciais. Neste trabalho, objetivou-se o desenvolvimento de pão de queijo enriquecido com farinha integral de feijão-caupi biofortificado e avaliar sua aceitação e composição química. Foram elaboradas duas formulações de pão de queijo, F1 e F2, contendo 5,6 e 8\% de farinha de feijão-caupi em substituição ao polvilho, respectivamente. Para verificar a aceitação, utilizaram-se três testes sensoriais (Escala Hedônica, Intenção de Compra e Comparação Pareada), sendo a F1 viável, sensorialmente, de acordo com os assessores, sendo analisada quimicamente. Os minerais foram determinados por espectrometria de emissão atômica com fonte de plasma indutivamente acoplado. Determinou-se a umidade por secagem em estufa a $105^{\circ} \mathrm{C}$, cinzas por calcinação em mufla a $550{ }^{\circ} \mathrm{C}$, proteínas pelo método macro-Kjeldahl e lipídios por extração a quente em extrator de Soxhlet. Os carboidratos foram obtidos por diferença e calculou-se o valor calórico. O acréscimo de feijão-caupi aumentou os teores de cobre, ferro, fósforo, magnésio, manganês e zinco, além dos valores referentes às proteínas e carboidratos. Por outro lado, ocorreu a redução dos teores de umidade, lipídios e valor calórico total, quando comparado à formulação padrão. Conclui-se, portanto, que o feijão-caupi, uma matériaprima regional e em expansão no mercado, apresenta-se como uma opção para o enriquecimento de alimentos de panificação sem glúten, como o pão de queijo.

Termos para indexação: Produto de panificação; fortificação; Vigna unguiculata (L.) Walp. 


\section{INTRODUCTION}

Cheese bread is a bakery product obtained primarily by scalding starch with water (or milk) and oil, mixing it with eggs, adding cheese and baking powder. The type of starch used (sweet, sour, or a mixture of the two) in cheese bread can also be varied. However, cheese breads made with sweet starch has its standardization facilitated for having more stable physicochemical characteristics. Cheese bread is a traditional product of the state of Minas Gerais, and its production has been increasing in recent years with the expansion of the market, which includes exportation (Anjos et al., 2014; Machado; Pereira, 2010).

The cowpea, also called black-eyed pea or Southern pea [Vigna unguiculata (L.) Walp], is a staple food for lowincome populations of the Northeastern of Brazil, and its cultivation is a major source of income and employment in this region. Such vegetable has an important role in human nutrition because it is an important source of proteins and carbohydrates, presenting considerable contents of fibre, vitamins (thiamin, niacin, riboflavin, pyridoxine, and folacin), and minerals (phosphorus, iron, potassium, magnesium, zinc and manganese), as well as low amounts of lipids, especially unsaturated fatty acids (Freire Filho et al., 2011).

According to the ordinance $\mathrm{n}^{\circ} 31$ of January 13 th of 1998, fortification and enrichment of food are terms used to describe the process of adding one or more essential nutrients that can be naturally contained in the food or not, to fortify its nutritional value and/or to prevent or correct deficiencies demonstrated in one or more nutrients of the diet of the general population or specific population groups (Brasil, 1998). Fortification has several advantages, including great acceptance by the population, since it does not change eating habits and presents low risks of toxicity because of its large margin of safety (Taddei et al., 2011).

In addition to the increase in nutrient content, the starch from cowpea improves the technology of quality of bakery products when compared to conventional sources of starch (cassava, corn, potato, and rice). With starch in beans, batters have lower amounts of specific gravity, which increases the product's specific volume, enlightens color, not allowing the reduction of humidity during the period of storage. And also, the best values regarding texture attributes during shelf life may lead to greater scores in the sensory evaluation, especially for attributes of crumb and texture (moisture, smoothness, and softness) (Almeida; Marangoni and Steel, 2013).
In the present study, we enriched a product commonly consumed by the general population, and whose market has been increasing. This practice represents an important strategy to serve the interests of the consumers by providing products with better nutritional value. Regional raw materials that are easy to obtain and prepare allow cheese bread to be enriched, contributing to the satisfaction of the daily nutrient requirements of the population. Thus, the objective of the present study was to develop a recipe of cheese bread enriched with whole biofortified cowpea flour (CF) of good sensory acceptance and with nutritional characteristics superior to the standard formulation.

\section{MATERIAL AND METHODS}

\section{Raw materials}

Samples of biofortified cowpea BRS Xiquexique came from the experimental field of the Brazilian Corporation of Agricultural Research (Embrapa Mid-North), Teresina, Piauí, Brazil, which is 72 meters high, being located $5^{\circ} 5^{\prime}$ South latitude, and $42^{\circ} 48^{\prime}$ 'West longitude. Other raw materials used in the formulations, such as sweet starch, whole milk, soybean oil, parmesan cheese, eggs, and salt were obtained in local markets.

\section{Cowpea flour production}

The whole cowpea flour was produced according to Frota et al. (2010). Grains of the BRS Xiquexique cultivar were milled in a semi-industrial mill (Tecnal model TE651/2-T). The flour was stored in polyethylene bags under refrigeration $\left(8^{\circ} \mathrm{C}\right)$ until the moment of use.

\section{Cheese bread formulation}

Formulations were prepared by following the steps described in Pereira et al. (2004). The dry raw materials (starch and CF) were mixed and then scalded with the liquids (water or milk with oil and salt), being heated to $85^{\circ} \mathrm{C}$. The mixture was manually homogenised, and then, after five minutes, a fresh egg was added (the egg white and the yolk were premixed for easy addition). After three minutes, parmesan cheese was added to the formulation, and the dough was manually shaped into balls. The balls of dough were baked in an electric oven for 25 minutes at $180^{\circ} \mathrm{C}$. In the standard formulation, only the sweet starch was considered dry material to be scalded. To obtain formulations, the same conditions of time and temperature were kept. 
To obtain viable options for the next stage (sensory analysis of the products), different formulations and cooking times were tested, and the products were evaluated by trained assessors, who were participants of the project, with the objective of improving the formulations. Two formulations were prepared, in which the sweet starch and the $\mathrm{CF}$ were the only raw materials whose percentages varied (Table 1). Formulations were developed by tests conducted in the Laboratory of Product Development and Sensory Analysis of Food (Department of Nutrition - UFPI).

Table 1: Percentage of raw materials used in standard cheese bread formulations and in formulations enriched with CF after laboratory tests.

\begin{tabular}{cccc}
\hline Raw materials & Standard (\%) & F1 (\%) & F2 (\%) \\
\hline Sweet starch & 45 & 39.4 & 37 \\
CF & - & 5.6 & 8 \\
Whole milk & 27 & 27 & 27 \\
Soybean oil & 6 & 6 & 6 \\
lodised salt & 1 & 1 & 1 \\
Egg white & 10 & 10 & 10 \\
Parmesan cheese & 11 & 11 & 11 \\
\hline TOTAL & 100 & 100 & 100 \\
\hline
\end{tabular}

\section{Sensory analysis}

The sensory analysis of formulations F1 and F2 was performed by a team of 100 untrained assessors of both genders, aged between 18 and 50 years, who were potential consumers of the product, and who were recruited among students, staff, and professors of the Federal University of Piauí after signing an informed consent form.

To investigate the overall acceptance of the products, we used a nine-point hedonic scale (1 "extremely disliked" to 9 "extremely liked"), estimated purchase intent (1 "would certainly not buy it" to 5 "would certainly buy it"), and a discrimination test of paired comparison (in which the minimum preference number to establish a significant difference among samples at a significance level of 5\% was of 100 assessors), to obtain at least 61 answers regarding the preferred formulation and identify differences (two-tailed), according to Ferreira et al. (2000).

We used a completely randomized design, and all the sensory assessors evaluated the three samples of the product. We also have adopted the balanced presentation order, so that each cheese bread was presented many times and in every position to control the effects of first order and of reporting (Albuquerque et al., 2009).

\section{Mineral content}

The calcium $(\mathrm{Ca})$, copper $(\mathrm{Cu})$, iron $(\mathrm{Fe})$, phosphorus $(\mathrm{P})$, sodium $(\mathrm{Na})$, magnesium $(\mathrm{Mg})$, manganese $(\mathrm{Mn})$, and zinc $(\mathrm{Zn})$ mineral contents were determined using an adapted Inductively Coupled Plasma-Optic Emission Spectrometry (ICP-OES) technique, by following Horwitz and Latimer (2000). After the mineralisation, the samples were put in a muffle furnace at $450{ }^{\circ} \mathrm{C}$ (model Q-318 M21, Quimis, São Paulo, Brazil). The original method was adapted regarding its wavelengths to analyze each mineral as follows: calcium, 317.933; copper, 324.754; iron, 259.940; phosphorus, 213.618; sodium, 589.592; magnesium, 279.553; manganese, 257.610; and zinc 206.200. Prior to the determination of the minerals, the materials used were decontaminated in a $20 \%$ nitric acid solution for 24 hours. These analyses were performed in triplicate at the Food Science and Quality Centre, ITAL, São Paulo (SP).

\section{Proximate composition}

The moisture was determined by drying in an oven (314D242 model, Quimis, São Paulo, Brazil) at $105{ }^{\circ} \mathrm{C}$ until a constant weight was obtained. The ash content was determined after calcination in a muffle furnace (model Q-318 M21, Quimis, São Paulo, Brazil) at $550{ }^{\circ} \mathrm{C}$. The protein concentration was determined using the macroKjeldahl method with a conversion factor of 6.25 , and the lipid content was determined by hot extraction using hexane as solvent in a Soxhlet apparatus (TE-044, Tecnal, São Paulo, Brazil) (Association Of Official Analytical Chemistry-Aoac, 2005). The carbohydrate content was calculated by difference, and the calorific value was calculated according to Atwater conversion factors (Watt and Merrill, 1963). These analyses were performed in triplicate at the Laboratory of Food Science and Food Biochemistry (Department of Nutrition - UFPI).

\section{Statistical analysis}

The Statistical Package for the Social Sciences version 17 was used for the data analysis. We used the chisquare test for differences between the proportions of the paired comparisons, and the student's t-test for differences between the means of formulations. A significance level of 5\% was adopted (Andrade, 2013).

\section{Ethical aspects}

The participants of the study have voluntarily signed an informed consent form in accordance with the Resolution $n^{\circ}$ 196/96 (Brasil, 1996) and the Resolution $n^{\circ}$ $466 / 2012$ of the National Health Council (Brasil, 2012). 
The study's protocol was examined and approved by the Research Ethics Committee of the Federal University of Piauí (CAAE: 0178.0.045.000-11).

\section{RESULTS AND DISCUSSION}

\section{Sensory evaluation}

The formulations F1 and F2 underwent affective (hedonic scale and purchase intent), and discriminative (paired comparison) tests (Table 2).

Table 2: Overall acceptance of cheese bread enriched with whole biofortified cowpea flour (Vigna unguiculata (L.) Walp).

\begin{tabular}{cc}
\hline Samples & $\begin{array}{c}\text { Overall acceptance (score) } \\
\text { Mean } \pm \text { SD }\end{array}$ \\
\hline F1 & $7.28 \pm 0.03 \mathrm{a}$ \\
F2 & $6.62 \pm 0.01 \mathrm{~b}$ \\
\hline
\end{tabular}

According to Table 2, both formulations obtained satisfactory acceptance levels with means greater than 6 ("slightly liked it"). The student's t-test indicated a significant difference $(p<0.05)$ between formulations. The F1 accepting average showed values close to those obtained in a research by Andrade et al. (2011) developed with potatoes and cassava bread, both enriched with white bean flour, presenting averages of 7.2 and 7.4, respectively.

Almeida, Marangoni and Steel (2013) attribute the acceptance of bakery products enriched with cowpea to the technological properties of this vegetable starch in formulations, the obtaining of a product with a suitable texture and color, with greater air entrainment, and high specific volume.

The second test performed by the team of untrained assessors was the test of purchase intent (Figure 1).

As it was noted, advisers showed $67 \%$ and $50 \%$ of positive intentions ("would certainly buy" and "would probably buy" the product) for F1 and F2, respectively. The results of this test support the products' acceptance by assessors, and show a greater tendency of purchase for F1.

The results of the paired comparison test were favourable for the F1 formulation. This result was similar to what was reported by Frota et al. (2010), which showed that the most widely accepted of the three formulations of different amounts of CF in cookies had the lowest CF content (Table 3).

According to the sensory analysis, the F1 formulation had better commercial potential and acceptance, with more favourable results compared to the F2. Thus, the F1 was considered the sensorially selected sample. Subsequent proximate composition steps were performed using F1 to make comparisons with the standard product.

\section{Mineral content}

Cowpea flour was considered appropriate for the enrichment of cheese bread. As CF was added to the product, the contents of the minerals analysed have increased, and only the calcium and sodium contents have reduced. The reduction in sodium was important, because such mineral is known to be highly present in the compositions of processed foods. Thus, to produce a product whose sodium concentration is significantly lower than in the standard is important. The $\mathrm{CF}$ in $\mathrm{F} 1$ has increased the amounts of copper, magnesium, and manganese by $2.3,1.8$, and 3.3 -fold, respectively, when compared to the standard formulation (Table 4).

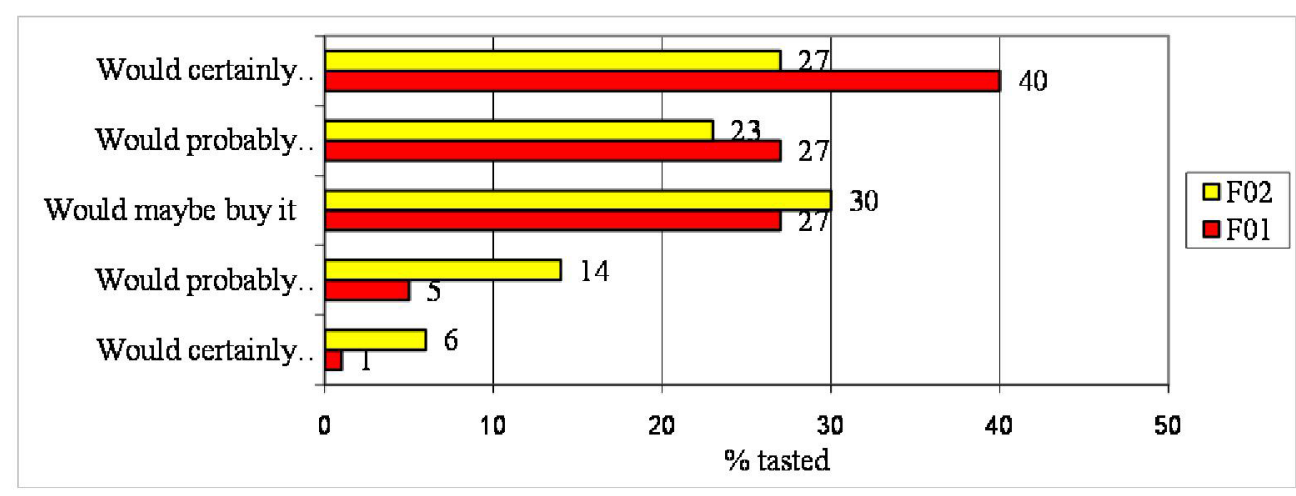

Figure 1: Purchase intent for cheese bread formulations enriched with whole biofortified cowpea flour (Vigna unguiculata (L.) Walp). 
Table 3: Paired comparison test between the cheese bread formulations.

\begin{tabular}{cccc}
\hline Formulations & $\begin{array}{c}\text { Number of } \\
\text { assessors }\end{array}$ & $\%$ & Statistic \\
\hline F1 & 67 & 67.0 & \\
F2 & 33 & 33.0 & $\chi^{2}=23.10$ \\
TOTAL & 100 & 100 & $\mathrm{p}<0.001$ \\
\hline
\end{tabular}

The cowpea flour doubled the amount of iron in F1 compared to the standard recipe. The increased iron and zinc values were expected because the BRS Xiquexique cultivar is biofortified and has high contents of these minerals, which are important to human nutrition since deficiency-related diseases are still highly prevalent.

Foods that are already part of the eating habits of the population should be fortified, mainly with regional raw materials that are easy to obtain and also sources of micronutrients, because the current food choices are poor regarding micronutrients. When comparing the RDI of reference with the amount of minerals present in $100 \mathrm{~g}$ of cheese bread, Table 4 shows that the formulation developed have met approximately half of the RDI for calcium, phosphorus and zinc and 12\% of RDI for iron.

According to the Resolution 54 of November 12 of 2012, the Brazilian Health Surveillance Agency (ANVISA) (Brasil, 2012), solid foods enriched with nutrients that provide at least $15 \%$ of the RDI of reference can receive the label "source". Therefore, F1 is a source of calcium, phosphorus, sodium, magnesium, and zinc. The RDI of reference used was for children aged between 4 and 6 years, because this group has a greater susceptibility to deficiency-related diseases and are potential consumers of the product.

\section{Chemical composition and total energy value (TEV)}

According to Table 5, formulations showed no statistically significant difference compared to the ash content. This result can be derived from the percentage of CF in F1, as Frota et al. (2010) has observed by an increase in the ash content of baked products, in which the addition of cowpea was of $20 \%$.

There was a decrease in moisture when sweet starch was partially substituted by CF (Table 5). Frota et al. (2010) have added $\mathrm{CF}$ in products such as cookies, and reported no significant differences between formulations with and without $\mathrm{CF}$, but the authors did observe a decrease in the moisture content in Swiss rolls when the CF percentage increased, as seen in the present study.

Standard formulations and F1 have lower lipid levels than those determined by Lemos et al. (2012) in standard cheese bread formulation (20.7\%). Despite the fact the addition of CF has promoted a decrease in lipid content of the formulation, Oladunmoye, Akinoso and Olapade (2010) have found the lipid content increases in breads that replaced wheat flour with cassava and cowpea.

The increase in protein content, as shown in Table 5, was one of the goals of the preparation of fortified cheese breads, considering the protein content of vegetables is well known. Besides increasing the protein content, the cowpea improves the amino acids' profile, which is provided in the product, since such raw material presents all essential amino acids. Lysine is particularly deficient in cereals such as in flour, the main raw material of cheese breads. This partial substitution was relevant since F1 had higher protein content compared to the obtained by Lemos et al. (2012): $6.8 \%$ in cheese breads with $10 \%$ amaranth flour.

Table 4: Mineral contents of the standard cheese bread and of the formulation F1 and the percentage of fulfilment of the recommended daily intake (RDI) for children aged between 4 and 6 years.

\begin{tabular}{ccccc}
\hline \multirow{2}{*}{ Minerals } & \multicolumn{2}{c}{ Standard cheese bread mg/100 } & \multicolumn{2}{c}{ F1 $(5.6 \%$ CF) $\mathrm{mg} / 100 \mathrm{~g}$} \\
\cline { 2 - 5 } & Mean $+\mathrm{SD}$ & \%RDI & Mean + SD & \%RDI \\
\hline Calcium & $251 \pm 1.00 \mathrm{a}$ & 42 & $244 \pm 5.00 \mathrm{~b}$ & 41 \\
Copper & $0.021 \pm 0.001 \mathrm{a}$ & 5 & $0.048 \pm 0.002 \mathrm{~b}$ & 11 \\
Iron & $0.34 \pm 0.01 \mathrm{a}$ & 6 & $0.72 \pm 0.01 \mathrm{~b}$ & 12 \\
Phosphorus & $187 \pm 1.00 \mathrm{a}$ & 37 & $210 \pm 1.00 \mathrm{~b}$ & 42 \\
Sodium & $699 \pm 18.00 \mathrm{a}$ & 58 & $649 \pm 26.00 \mathrm{~b}$ & 54 \\
Magnesium & $12.3 \pm 0.20 \mathrm{a}$ & 17 & $22.6 \pm 0.30 \mathrm{~b}$ & 31 \\
Manganese & $0.029 \pm 0.003 \mathrm{a}$ & 2 & $0.097 \pm 0.003 \mathrm{~b}$ & 6 \\
Zinc & $1.87 \pm 0.01 \mathrm{a}$ & 37 & $2.39 \pm 0.04 \mathrm{~b}$ & 48 \\
\hline
\end{tabular}

* The RDI for children aged between 4 and 6 years was considered (Brasil, 2005). The same letter in a row indicates that there is no significant difference at the $p<0.05$ level according to the student's t-test. 
Table 5: Mean and standard deviation of the proximate composition and total energy value (TEV) of cheese bread formulations.

\begin{tabular}{ccccccc}
\hline Formulations & Ashes (\%) & Moisture (\%) & \multicolumn{1}{c}{ Lipids (\%) } & Protein (\%) & Carbohydrates (\%) & $($ Kcal/ KJoule) \\
\hline Standard & $2.6 \mathrm{a}( \pm 0.01)$ & $29.9 \mathrm{a}( \pm 2.01)$ & $11.8 \mathrm{a}( \pm 0.19)$ & $8.8 \mathrm{a}( \pm 0.31)$ & $46.9 \mathrm{a}( \pm 3.22)$ & $329 / 1376.5 \mathrm{a}$ \\
F1 & $2.9 \mathrm{a}( \pm 0.02)$ & $26.9 \mathrm{~b}( \pm 1.78)$ & $8.1 \mathrm{~b}( \pm 0.10)$ & $10.6 \mathrm{~b}( \pm 0.25)$ & $51.5 \mathrm{~b}( \pm 5.21)$ & $321.3 / 1344 \mathrm{~b}$ \\
\hline
\end{tabular}

The same letter in a column indicates that there is no significant difference between the means according to the student's t-test $(p<0.05)$.

The protein value of $\mathrm{F} 1$ was also higher than that of cookies with $10 \% \mathrm{CF}$ and Swiss rolls with $10 \%$ and $20 \%$ CF developed by Frota et al. (2010).

Table 5 shows that the carbohydrate content was significant in cheese breads, which confirms the product is an energy-dense food. The use of a whole meal in the partial replacement of starch may have contributed to the increase in the carbohydrate content of $\mathrm{F} 1$, a relevant increase when considering the presence of dietary fiber in the product formulated.

Caloric values of both samples were smaller than the ones developed by Lemos et al. (2012) (356 kcal/1489.5 KJoule).

The proximate composition emphasises the quality of the product. The percentage contribution to the RDI for carbohydrates and lipids was greater than $30 \%$, and the percentage contribution to the RDI for protein was $55.8 \%$ (Table 6). Considering the F1 was accepted in the sensory analysis, and had increased contents of minerals and macronutrients, the partial replacement of sweet starch by CF in cheese bread production was found to be possible and relevant.

Table 6: Percentage of recommended daily intake (RDI) for macronutrients' fulfilment.

\begin{tabular}{cc}
\hline Macronutrients & \% RDI \\
\hline Carbohydrates & 39.6 \\
Lipids & 32.4 \\
Proteins & 55.8 \\
\hline
\end{tabular}

*The RDI for children aged between 4 and 6 years was considered (Brasil, 2005).

\section{CONCLUSIONS}

Among the formulations enriched with wholewheat flour cowpea, the F1 presented higher acceptance values compared to $\mathrm{F} 2$, thus being the one selected.

It was observed that the cowpea addition has increased the levels of minerals, copper, iron, phosphorus, magnesium, manganese, and zinc and has decreased sodium and calcium levels.

The F1 has presented decreased moisture, lipids, and the total caloric value, with addition of proteins and carbohydrates when compared to the standard formulation.

Cowpea, a regional raw material that has been gaining space in the market is a valid option for the enrichment of gluten free baked foods such as cheese breads.

\section{REFERENCES}

ALBUQUERQUE, T. L. et al. Processamento e aceitação sensorial de produto do tipo hambúrguer à base de soja (Glycine max) e atum (Thunnus spp). Boletim do CEPPA, 27(2): 191-198, 2009.

ALMEIDA, E. L.; MARANGONI, A. L.; STEEL, C. J. Starches from non - conventional sources to improve the technological characteristics of pound cake. Ciência Rural, 43(11): 2101 2108, 2013.

ANDRADE, A. A. de et al. Sensory evaluation of bakery flour enriched with white beans for celiac patients. Nutrir Gerais, 5(8):727-739, 2011.

ANDRADE, D. F. Statistics for agrarian and biological sciences: experimental concepts. 3 ed. Florianópolis: Ed. da UFSC, 2013. 475p.

ANJOS, L. D. dos et al. Modified starches or stabilizers in preparation of cheese bread. Ciência Rural, 44(9):16861691, 2014.

ASSOCIATION OF OFFICIAL ANALYTICAL CHEMISTRY - AOAC. Official Methods of Analysis of the AOAC International. 16 ed. Arlington: AOAC, 2005. 1025p.

BRASIL. Ministério da Saúde. Agência Nacional de Vigilância Sanitária. ANVISA. Resolução $n^{\circ} .54$ de 12 de novembro de 2012. Dispõe sobre o Regulamento Técnico sobre Informação Nutricional Complementar. Diário Oficial da República Federativa do Brasil. Brasília. DF. 19 de novembro de 2012. 
BRASIL. Ministério da Saúde. Agência Nacional de Vigilância Sanitária. ANVISA. Resolução $n^{\circ} 269$ de 22 de setembro de 2005. Dispõe sobre o regulamento técnico sobre a ingestão diária recomendada (IDR) de proteína, vitaminas e minerais. Diário Oficial da República Federativa do Brasil. Brasília. DF. 22 de setembro de 2005.

BRASIL. Ministério da Saúde. Conselho Nacional de Saúde. Resolução $n^{\circ}$. 196 de 10 de outubro de 1996. Aprova as diretrizes e normas regulamentadoras de pesquisas envolvendo seres humanos. Diário Oficial da República Federativa do Brasil. Brasília. DF, 10 de outubro de 1996.

BRASIL. Ministério da Saúde. Conselho Nacional de Saúde. Resolução $n^{\circ}$. 466 de 12 de dezembro de 2012. Dispõe sobre as diretrizes e normas regulamentadoras de pesquisas envolvendo seres humanos. Diário Oficial da República Federativa do Brasil. Brasília. DF, 13 de junho 2013.

BRASIL. Portaria n 31 de 13 de janeiro de 1998. Aprova o regulamento técnico referente a alimentos adicionados de nutrientes essenciais. Diário Oficial da República Federativa do Brasil. Brasília. DF, 16 de janeiro de 1998.

FERREIRA, V. L. P. et al. Sensory Analysis: discriminative and affective tests. v.1. Campinas: SBCTA, 2000. 127p.

FREIRE FILHO, F. R. et al. Feijão-caupi no Brasil: produção, melhoramento genético, avanços e desafios. v.1. Teresina: Embrapa Meio-Norte, 2011.81p.

FROTA, K. M. G. et al. Utilisation of cowpea (Vigna unguiculata (L.) Walp) flour in the development of bakery products. Ciência e Tecnologia de Alimentos, 30(1):44-50, 2010.

HORWITZ, W.; LATIMER JUNIOR, G. Official Methods of Analysis of the Association of Official Analytical Chemists. 17 ed. Gaithersburg, Maryland: AOAC, 2000, v.2, Chap.50 (met. 985.35; 984.27, 15-18p.).

LEMOS, A. R. et al. Effect of incorporation of amaranth on the physical properties and nutritional value of cheese bread. Ciência e Tecnologia de Alimentos, 32(3):427-431, 2012.

MACHADO, A. V.; PEREIRA, J. Effect of scalding on technological and rheological properties of cheese bread dough and cheese bread. Ciência e Agrotecnologia, 34(2):421-427, 2010.

OLADUNMOYE, O.; AKINOSO, R.; OLAPADE, A. Evaluation of some physical-chemical properties of wheat, cassava, maize and cowpea flours for bread making. Journal of Food Quality, 33(6):693-708, 2010.

PEREIRA, J. et al. Function of the ingredients in the consistency of the dough and the characteristics of the cheese breads. Ciência e Tecnologia de Alimentos, 24(4):494-500, 2004.

TADDEI, J. A. A. C. T. et al. Nutrition in Public Health. v.1. Rio de Janeiro: Editora Rubio, 2011. 664p.

WATT, B.; MERRILL, A. L. Composition of foods: raw, processed, prepared. DC: Consumer and Food Economics Research. Divison (USDA), Washington, 1963. 190p. (Agriculture Handbook, 8). 